Borneo Journal of Sciences and Technology, Volume (1), Issue (1), Pages: 01-02

DOI: https://doi.org/10.35370/bjost.2019.1.1-01

e-ISSN: 2672-7439

(C) 2018, UCTS Publisher.

\title{
Enhancing the Development of Engineered Wood Products in Sarawak
}

\author{
Razak Wahab \\ School of Engineering and Technology, University College of Technology Sarawak, 96000 Sibu, \\ Sarawak, Malaysia
}

\begin{abstract}
Engineered wood (composite wood, man-made wood, or manufactured board) includes a range of derivative wood products manufactured by binding the strands, particles, fibers, or veneers or boards of wood, together with adhesives to form composite materials. These products are engineered to precise design specifications which are tested to meet national or international standards. Sarawak with an area 124,450 sq km, produced wood and timber products of 5,275,832 metric tons for 2012 in export earnings. The production of this product mainly focused on upstream industries i.e. sawn timbers, plywood, veneer, wood molding, laminated boards, particleboards, MDF, woodchip, charcoal / briquette, laminated flooring and wood pellets. Timber downstream industries such as furniture that can generate high income have not been established yet in Sarawak. The furniture used in the state are still being carried from factories in Peninsular Malaysia or imported from other countries. With Permanent Forest \& Forest Plantation covering 6 million ha and 2.8 million ha respectively, the Sarawak state government intends to increase the production of downstream timber industry equivalent to the existing industry in Peninsular. Timber downstream industries i.e. furniture \& construction materials that generate high income have not established yet in Sarawak.
\end{abstract}

Keywords: forest plantation, enhancing wood down-stream industry, engineered wood products, Centre of Excellence Engineered Wood Products

\section{INTRODUCTION}

The Centre of Excellence for Wood Engineered Products (CeWEP) was launched and established on the 22 November 2017 at UCTS. CeWEP was established as a catalyst to enhance the participation and engagement of local timber industry to produce and export more of the finished products rather than upstream products. Sarawak is one of the states in Malaysia that rich in natural resources especially wood. However, the production of wood products still focused on upstream products like sawn timber, plywood, veneer, laminated boards, particleboards etc. The downstream industry of wood products which would bring more profit to the state especially furniture is still under-developed.

Thus, under the Sarawak Corridor of Renewable Energy (SCORE), the timber-based industry is named as one of the priority industries aside from oil and gas, marine engineering, tourism and aquaculture and others. Sarawak clearly defines their strategy to develop its timber product industry to encourage the wood industry to migrate from the basic commodity timber production into manufacturing high-value components and finished goods for export.

CeWEP not only focuses on the processing of wood to produce engineered wood products with high quality but also with the latest design. Besides, since the centre concentrates more on lesser-known wood species and local wood species, the topics of biodiversity is another crucial consideration.

This CoE is currently working with various organisations such as Forestry Research Institute of Malaysia (FRIM), Sarawak Timber Industry Corporation (STIDC), Sarawak Timber Association (STA), Sarawak Forestry Department, Sarawak Forestry Corporation (SFC) and local wood industry to achieve its objective and KPIs.

\section{OBJECTIVES}

1. To developed advanced engineered wood products from local wood species especially the planted timber in Sarawak

2. To produced engineered wood products of lesserknown species with low maturity age for houses construction and furniture. 
3. To protect the biodiversity of tree species in Sarawak by promoting the use of plantation wood.

\section{NICHE}

1. Sustainable and renewable materials

2. Biodiversity

\section{SHORT-TERM KPI}

1. In-house development of engineered wood products.

2. Acquiring new skills among members of CeWEP.

3. As the leading research centre for wood-based products in Sarawak.

4. To conduct training for local timber-based industry.

\section{LONG-TERM KPI}

1. Increase in the export of engineered wood products in the timber industry around Sarawak.

2. Utilization of engineered wood products as one of main building and construction materials.

3. Increased the income for local communities and state government.

\section{STRATEGIC PLANNING}

1. Training the members in the centre of excellence and from industry regarding the new products.

2. Analysis or assessment in producing or utilizing of: i) New engineered products or

ii) New product design or New wood

3. Laboratory works or field works on the subject of interest

i) Introduction of new engineered products or product design or wood species through exhibition.

ii) Getting feed back

4. Evaluation of the new wood species or new wood products for its marketability and marketing

\section{RESEARCH}

Following are the research that is currently on-going or proposed under CeWEP.

1. Thermoplastic wood composite from agriculture residues of Kenaf bast, Elaeis guneensis, Cassava bagasse and Thermeda arguens,

2. Evaluation of Four Composts from Wood Waste of Planted Timber Species for Peat Substitution in Nursery Utilization,

3. Wood Plastic Laminates from Acacia mangium Veneer and Thermoplastic Starch Sheet with Nanocellulose Fibril Filler,

4. Bamboo and Gypsum Boards for Sound-Absorbing Application,
5. The Parallel and Cross Laminated Boards as the main Construction Materials for Low and Medium Cost Houses from Cultivated Timber Species in Sarawak,

6. Assessment on Four Wood Waste of Planted Timber Species for Peat Substitution in Nursery Management,

7. Plastic Laminated Panels (PLP) from Wood and Non-Wood Veneer and Thermoplastic Starch Sheet with Nanocellulose Fibril Filler as Plastic Substitute,

8. Hybrids of Acoustical Composites from Bambusa vulgaris and Gypsum Board for Sound Absorption 